\title{
Comparison of estrogen compounds removal efficiency in sample and alternating anoxic/aerobic activated sludge process
}

\author{
Dalel Belhaj ${ }^{\mathrm{a}^{*}}$, Nesrine Turki ${ }^{\mathrm{b}}$, IkramJaabiric ${ }^{\mathrm{c}}$, Moneem Kallel ${ }^{\mathrm{d}}$, Habib Ayadi ${ }^{\mathrm{e}}$, \\ John L. Zhou ${ }^{\mathrm{f}}$ \\ ${ }^{*} a, b, c, d$ Laboratory of Water-Energy-Environment, University of Sfax-Tunisia, ENIS Street Soukra Km 3.5, BP \\ 1173 CP 3038, Sfax \\ ${ }^{e}$ Faculty of Sciences, Departement of Life Sciences, Laboratory of Biodiversity and Aquatic \\ Ecosystems, Ecology and Planktonology, University of Sfax-Tunisia, \\ Street Soukra Km 3.5,BP 1171 CP 3000, Sfax, Tunisia \\ ${ }^{f}$ Department of Applied Science, London South Bank University, SE1 OAA, London, UK
}

\begin{abstract}
The occurrence and the removal efficiency of natural estrogens, estrone (E1), 17ק-estradiol (E2) and estriol (E3), as well as a synthetic estrogen, 17a-ethinylestradiol (EE2), were investigated in two sewage treatment plants (STPS) employing different activated sludge processes in Tunisia, by monitoring their concentrations in dissolved wastewater. The analytes were extracted by solid-phase extraction and then analyzed by gas chromatography coupled with mass spectrometry (GC-MS). Results indicate that natural and synthetic estrogens were detected in the STP influent samples. The concentrations of natural and synthetic estrogens (except E1) detected in the effluents of alternating activated sludge process were generally lower than the limit of detection. On the other hand, all estrogens were not totally removed through the simple activated sludge process; as a result, they were detected in effluent samples. E3 showed the highest concentration in the influent samples at $98 \mathrm{ng} \mathrm{L}^{-1}$ in the alternating anoxic/aerobic activated sludge process, and at $102 \mathrm{ng} \mathrm{L}^{-1}$ in the simple activated sludge. Two different types of diurnal variation of estrogens discharge were identified. The two STPs had approximately similar daily loads of estrogens in influents at $112.7 \mu \mathrm{g} d^{-1}$ and $109.58 \mu \mathrm{g} \mathrm{d} d^{-1}$, respectively. The distribution of estrogens in the STPs is affected by their metabolisms in human body and their transition through biological treatment processes. Removal efficiency varied among STPs; high removal of estrogens (84-97\%) with the exception of E1 (80\%), were generally achieved in alternating anoxic/aerobic activated sludge process with a high hydraulic retention time $(40 \mathrm{~h})$ and treatment stages for removal of nitrogen. E1 showed the lowest removal of all estrogens in the two STPs. This could be caused by conversion of E2 to E1 in the treatment process, or by cleavage of estrogen conjugates. On the other hand, E3 showed the highest removal of all estrogens both in alternating anoxic/aerobic and simple activated sludge processes at 97.5\% and $85.5 \%$, respectively). EE2, which is particularly sensitive to human consumption as the oral contraceptive, were removed by approximately $77.5 \%$ ) in the simple activated sludge process.

Filamentous bacteria were less effective in removal estrogens than protozoa.

Keywords: sewage treatment plants, estrogens, alternating anoxic/aerobic activated sludge, hydraulic retention time, extraction, gas chromatography-mass spectrometry, microscopic examination
\end{abstract}

\section{Introduction}

The growing population, urbanization and modernization have led to the release of many organic pollutants into the environment. In recent years, the presence of endocrine-disrupting chemicals (EDCs) in the environment has been a major concern worldwide because they may alter the normal hormone functions as well as physiological status in wildlife and humans (Mills and Chichester, 2005; Khanal et al., 2006 ). Various types of natural and synthetic chemical compounds including estrogens have been identified as EDCs. The estrogens of natural origin include 17ß-estradiol (E2) and its main metabolites (i.e., estrone (E1) and estriol (E3)), have been found to alter gonad differentiation and development, decrease fertility (Safe et al., 2000; Jobling et al., 2003) and sex ratio (Mackenzie et al.,2003), impair spermatogenesis (Lee et al., 2005), gonadal dysgenesis (Fort et al., 2004; Hecker et al., 2005), hermaphroditism (Hayes et al., 2003) and cause feminization (Levy et al., 2004; Kloas et al., 2006). In addition, 17 $\alpha$-ethinylestradiol (EE2) which is widely used as an oral contraceptive, can bind to the estrogen receptor and misregulate or interfere with normal biological responses. This synthetic hormone has caused feminization in several fish species (Kwak et al., 2001; Mills and Chichester, 2005), at concentrations as low as $0.1 \mathrm{ng} \mathrm{L}^{-1}$ (Purdom et al., 1994). Many studies have shown that municipal sewage treatment plants (STPs) are a significant point source of EDCs released into the environment (Lee et al., 2002; Stasinakis et al., 2008; Zhang and Zhou, 2008; Zhou et al., 2009). EDCs discharge can exhibit seasonal, weekly and diurnal variation (Joss et al., 2005; Graver et al., 2011; Nie et al., 2011). 
Previous research showed that estrogenic hormones have been detected in influents and effluents of STP in many countries (Baronti et al., 2000; Jeannot et al., 2002; Stasinakis et al., 2010) and surface water (Boyd et al., 2004; kim et al., 2007; Stasinakis et al.,2008; Benotti et al., 2009; Grover et al., 2011). So far, the occurrence and removal of the EDCs in STPs has been well documented around the world (Nakada et al., 2006; Heidler and Halden, 2007; Stasinakis et al., 2008). Removal could be affected by both the compound specific properties, and the factors concerning specific STPs, such as the type of treatment processes, hydraulic retention time (HRT), and the biomass particle characteristics (Carballa et al., 2004; Nakada et al., 2006; Yi and Harper., 2007; Gulkowska et al., 2008). The current data suggest that wastewater treatment processes (e.g. activated sludge) have variable performance in removing EDCs. By comparing the influent and effluent estrogen concentrations, Baronti et al. (2000) concluded that the removal efficiency for estrone (E1) was 87\%. In a Brazilian STP, the observed removal efficiency for 17a-ethynylestradiol (EE2) ranged from $64 \%$ to $78 \%$ (Ternes et al., 1999). Sewage treatment processes in Italy removed $61-95 \%$ of these estrogenic compounds with median concentrations of E1 and EE2 of 9.3 and $0.45 \mathrm{ng} \mathrm{L}^{-1}$, respectively, in effluents after treatment (Baronti et al., 2000). However, there is little data to assess the performance of STP in Tunisia in removing estrogens, which is urgently needed to minimize adverse biological effects to the aquatic life in the country. The goals of this study were to investigate the occurrence of most potent natural and synthetic estrogens (E1, E2, E3 and EE2) in the dissolved phase of two Tunisian STPs, and to determine the removal efficiencies of these compounds between alternating anoxic/aerobic and simple activated sludge processes.

\subsection{Chemicals and standard solutions}

\section{Experimental}

All solvents used (methanol, ethyl acetate, dichloromethane and hexane) were of distilled-in glass grade (purchased from Rathburn Chemicals Ltd.,Walkerburn, Scotland). EDC standards including E1, E2, E3 and EE2, internal standard E2-d4 were obtained from Sigma and Qmx laboratories Ltd, UK, all with an isotopic purity $>98 \%$. Separate stock solutions of individual standards $\left(1000 \mathrm{mg} \mathrm{L}^{-1}\right)$ were prepared in methanol, from which working standards $\left(10 \mathrm{mg} \mathrm{L}^{-1}\right)$ of individual compounds and mixtures were prepared. All standards were stored at $-18{ }^{\circ} \mathrm{C}$. Ultrapure water was supplied by a Maxima Unit from USF Elga, UK.

\subsection{Sample collection}

Wastewater samples were collected from two STPs in Tunisia: Sfax and Sousse. These STPs employed similar treatment processes: a primary treatment using screening and grit settlement to remove particles coupled with a secondary biological treatment by activated sludge process. For the secondary treatment, STP at Sfax employed an alternating anoxic/aerobic process as biological treatment; while STP of Sousse employed a simple sludge process. Detailed information on the two STPs is summarized in Table 1.

To assess the occurrence and removal efficiencies of EDCs in STPs, composite samples over 24 hours from influent, aeration tank and effluent were collected in January and February 2011. To assess the daily variation in influent concentrations we performed a three day measurement campaign with the aid of automated samplers, set to collect samples at $2 \mathrm{~h}$ intervals. All sampling was conducted in duplicate and separately taken for later extraction and gas chromatography-mass spectrometry (GC-MS) analysis. Samples were collected in precleaned amber glass bottles $(2 \mathrm{~L})$ into which $1 \%$ formaldehyde $(\mathrm{v} / \mathrm{v})$ was added to inhibit the microbial activity, and then taken back to the laboratory for analysis. In the laboratory, the wastewater samples were acidified to pH 3.0 with $40 \% \mathrm{H}_{2} \mathrm{SO}_{4}(\mathrm{v} / \mathrm{v})$ and stored at $4{ }^{\circ} \mathrm{C}$ in refrigerator before analysis.

To monitor the purifying biomass, samples were collected from the mixed liquor at the end of the aeration tank in $50 \mathrm{~mL}$ plastic bottles. To ensure accurate measurement of the oxygen demand, only less than two-thirds of the volume of each bottle was occupied with the mixed liquor, and that the bottles were capped tightly.

Table 1. Operation conditions of investigated sewage treatment plants

\begin{tabular}{|c|c|c|}
\hline STP & Sfax & Sousse \\
\hline Rehabilitation & 2005 & 1996 \\
\hline Treatment process & $\begin{array}{l}\text { Activated sludge } \\
\text { (Low load) }\end{array}$ & $\begin{array}{l}\text { Activated sludge } \\
\text { (Average load) }\end{array}$ \\
\hline Treatment comments & $\begin{array}{c}\text { Alternating } \\
\text { anoxic/aerobic } \\
\text { activated sludge }\end{array}$ & $\begin{array}{c}\text { Simple activated } \\
\text { sludge }\end{array}$ \\
\hline Population equivalent & 526800 & 300000 \\
\hline Average flow $\left(\mathrm{m}^{3} \mathrm{~d}^{-1}\right)$ & 49500 & 17000 \\
\hline Data at simpling & & \\
\hline Influent flow $\left(\mathrm{m}^{3} \mathbf{d}^{-1}\right)$ & 50000 & 40000 \\
\hline $\begin{array}{l}\text { Aeration tank flow }\left(\mathrm{m}^{3} \mathrm{~d}^{-}\right. \\
\text {1) }\end{array}$ & 50000 & 8333 \\
\hline Effluent flow $\left(\mathrm{m}^{3} \mathbf{d}^{-1}\right)$ & 50000 & 17000 \\
\hline HRT (h) & 40 & 4 \\
\hline
\end{tabular}


Population equivalent IS the annual average data in 2011. HRT and the rate flow are the data at sampling

\subsection{Sample analysis \\ 2.3.1 General analysis}

Total nitrogen content and COD were determined by automatic microanalysis and colorimetric method, respectively (Hachicha et al., 2009). Phosphorus content was measured calorimetrically at $430 \mathrm{~nm}$ using a Shimadzu U 1000 spectrophotometer. Biochemical oxygen demand (BOD5) was determined by the manometric method with a respirometer (BSB-Controlled Model OxiTop (WTW).

\subsubsection{GC-MS analysis}

The target estrogens in the samples, including E1, E2, E3 and EE2, were determined according to the previously method modified by Belhaj et al. (2013). Briefly, samples (1L each) were filtered using precombusted Whatman GF/F filter paper $(0.7 \mu \mathrm{m})$ to remove particulate matter, and spiked with $100 \mathrm{ng}$ of E2- $\mathrm{d}_{2}$. These were ready for solid-phase extraction (SPE). First the SPE cartridges (Oasis HLB, Waters, USA) were conditioned with $5 \mathrm{ml}$ of ethyl acetate to remove residual bonding agents, followed by $5 \mathrm{~mL}$ of methanol and ultra-pure water $(2 * 5 \mathrm{~mL})$. Then wastewater samples were extracted at a flow rate less than $5 \mathrm{~mL} / \mathrm{min}$, which were subsequently eluted with $10 \mathrm{~mL}$ of ethyl acetate solvent. These extracts were concentrated to $1-2 \mathrm{~mL}$ under a gentle flow of nitrogen at $45^{\circ} \mathrm{C}$. They are derived by the addition of $50 \mu \mathrm{L}$ pyridine and $50 \mu \mathrm{L}$ BSTFA (to produce non-polar derivatives), which were heated at $65 \pm 5^{\circ} \mathrm{C}$ for $30 \mathrm{~min}$. These derivatives were cooled to room temperature, evaporated under a gentle stream of nitrogen to dryness and reconstituted in $100 \mu \mathrm{L}$ of hexane ready for the analysis by GC-MS.

GC-MS analysis was performed using a gas chromatograph (Trace GC 2000, Thermoquest CE Instruments, TX, USA) coupled with an ion trap mass spectrometer (Polaris Q, Thermoquest CE Instruments, Texas, USA) and an autosampler (AS 2000, Thermoquest).

A ZB5 (5\% diphenyl-95\% dimethylpolysiloxane) capillary column of $30 \mathrm{~m} \times 0.25 \mathrm{~mm}$ i.d. $(0.25 \mu \mathrm{m}$ film thickness) is used. Helium carrier gas was maintained at a constant flow rate of $1.5 \mathrm{~mL} / \mathrm{min}$. The GC column temperature was programmed from $100{ }^{\circ} \mathrm{C}$ (initial equilibrium time $1 \mathrm{~min}$ ) to $200{ }^{\circ} \mathrm{C}$ via a ramp of 10 ${ }^{\circ} \mathrm{C} / \mathrm{min}, 200-260{ }^{\circ} \mathrm{C}$ via a ramp of $15{ }^{\circ} \mathrm{C} / \mathrm{min}, 260-300{ }^{\circ} \mathrm{C}$ via a ramp of $3{ }^{\circ} \mathrm{C} / \mathrm{min}$ and maintained at $300{ }^{\circ} \mathrm{C}$ for $2 \mathrm{~min}$. The MS operates with electron impact ionization in full-scan mode from $50 \mathrm{~m} / \mathrm{z}$ to 600 for qualitative analysis. The inlet and MS transfer line temperatures were maintained at $280{ }^{\circ} \mathrm{C}$, and the ion source temperature is $250^{\circ} \mathrm{C}$. Sample injection $(1 \mu \mathrm{L})$ was in splitless mode.

\subsubsection{Microscopic analysis}

Examinations with phase contrast microscopy were made within $3 \mathrm{~h}$ after collection in order to avoid progressive temporal changes in density and in richness. $25 \mu \mathrm{L}$ sub-samples of mixed liquor were taken with $100 \mu \mathrm{L}$ automatic micropipette (Eikelboom., 2000; Zhou et al., 2006), and observed under phase-contrast illumination (100 x magnifications). The identification of species was carried out «in vivo» (Vedry., 1987).

\section{Results and discussion}

The dissolved concentrations of natural and synthetic estrogens and the removal rates as well as the wastewater characteristics are summarized, respectively, in Tables 2 and 3. Removal rates were calculated based on the influent and the effluent concentration. The effluent samples below the LOQ were calculated by using the value of LOQ ((E2: $0.8 \mathrm{ng} \mathrm{L}^{-1}$; EE2: $4.0 \mathrm{ng} \mathrm{L}^{-1}$; E3: $2.3 \mathrm{ng} \mathrm{L}^{-1}$; Nie et al., 2009) for the effluent concentration.

\subsection{Occurrence of estrogens in wastewater of Tunisian STPs}

Because each of the two STPs employed distinct secondary treatment units, the concentration of estrogens processed by the two WWTPs varied. The influent concentrations of E1 were approximately similar $\left(50 \mathrm{ng} \mathrm{L}^{-1}\right)$ in the two plants (Table 2). Those values are lower than those reported in Spain STPs with a median concentration of $115 \mathrm{ng} \mathrm{L}^{-1}$ (Petrovic et al., 2002) and similar to those reported in a survey conducted in Italy with a concentration of $52 \mathrm{ng} \mathrm{L}^{-1}$ (Baronti et al., 2000), but higher than those reported in surveys conducted in Paris with a concentration of $9.6 \mathrm{ng} \mathrm{L}^{-1}$ (Cargouët et al., 2004) and England with a concentration of $1.8 \mathrm{ng} / \mathrm{L}$ (Fawell et al., 2001). 
Table 2. Estrogen concentrations and removal efficiencies in Tunisian STPs (mean (SD), n=2). ND = not detected.

\begin{tabular}{|c|c|c|c|c|c|c|c|c|}
\hline & Sfax & & & & Sousse & & & \\
\hline \multirow[b]{2}{*}{ Influent } & E1 & E2 & EE2 & $\mathbf{E 3}$ & E1 & E2 & EE2 & $\mathbf{E 3}$ \\
\hline & $\begin{array}{c}50 \\
(1.2)\end{array}$ & $\begin{array}{l}10.8 \\
(0.3)\end{array}$ & $\begin{array}{l}25 \\
(1)\end{array}$ & $\begin{array}{c}98 \\
(2.1)\end{array}$ & $\begin{array}{c}51 \\
(0.2)\end{array}$ & $\begin{array}{c}19 \\
(0.4)\end{array}$ & $\begin{array}{c}45 \\
(0.1)\end{array}$ & $\begin{array}{c}102 \\
(1.4)\end{array}$ \\
\hline $\begin{array}{l}\text { Aeration } \\
\text { tank }\end{array}$ & $\begin{array}{l}53 \\
(1)\end{array}$ & $\begin{array}{c}6 \\
(0.9)\end{array}$ & $\begin{array}{c}22 \\
(0.9)\end{array}$ & $\begin{array}{c}67 \\
(1.4)\end{array}$ & $\begin{array}{c}18 \\
(0.9)\end{array}$ & $\begin{array}{c}11 \\
(0.4)\end{array}$ & $\begin{array}{c}13 \\
(0.6)\end{array}$ & $\begin{array}{c}50 \\
(2.1)\end{array}$ \\
\hline Effluent & $\begin{array}{l}10 \\
(1)\end{array}$ & ND & ND & ND & $\begin{array}{c}12 \\
(0.6)\end{array}$ & $\begin{array}{c}4 \\
(0.4)\end{array}$ & $\begin{array}{c}10 \\
(0.1)\end{array}$ & $\begin{array}{c}15 \\
(0.2)\end{array}$ \\
\hline Removal (\%) & 80 & $\geq 92$ & $\geq 84$ & $\geq 97.5$ & 76.5 & 79 & 77.5 & 85.5 \\
\hline
\end{tabular}

The influent concentrations of E2 in Sousse plant $\left(19 \mathrm{ng} \mathrm{L}^{-1}\right)$ were higher than those detected in Sfax plant (10.8 $\mathrm{ng} \mathrm{L}^{-1}$ ) (Table 2). This might be attributed to the highest daily amounts of deconjugated E2 excreted by tourists in Sousse, thus leading to an increase in the concentrations of E3 in the Sousse plant influents. Concentrations of E2 detected in Tunisian plants were similar to the previous surveys in Japan with a range of < 0.8-21 ng L ${ }^{-1}$ (Komori et al., 2004) and in Italy with a range of 4.0-25 ng L (Baronti et al., 2000).

E3, the highest concentration detected in influents of the two plants, is excreted in the largest amount by humans (Ternes and Joss, 2006). The influent concentrations of E3 in Sousse plant (102 ng L ${ }^{-1}$ ) were slightly higher than those detected in Sfax plant $\left(98 \mathrm{ng} \mathrm{L}^{-1}\right)$, which might be attributed to the highest concentrations of E2 in Sousse influents. Concentrations of E3 in Tunisian plants were generally lower than those reported by Nie et al. (2011) with a concentration of $459 \mathrm{ng} \mathrm{L}^{-1}$ and similar to those reported by Komori et al (2004) with a median value of $110 \mathrm{ng} \mathrm{L}^{-1}$.

The influents of Sfax and Sousse plants are contaminated with synthetic estrogen EE2 (used in contraceptive pills) which are more resistant to degradation than natural estrogens. The influent concentrations of EE2 in Sousse plant $\left(45 \mathrm{ng} \mathrm{L}^{-1}\right)$ were higher than those detected in Sfax plant $\left(25 \mathrm{ng} \mathrm{L}^{-1}\right)$, this can be ascribed to higher consumption of the contraceptives in Sousse. These results are coherent with this reported in the literature (Miege et al., 2009).

The influent EDC concentrations changed with time during 24-h periods, as show in Fig 1.

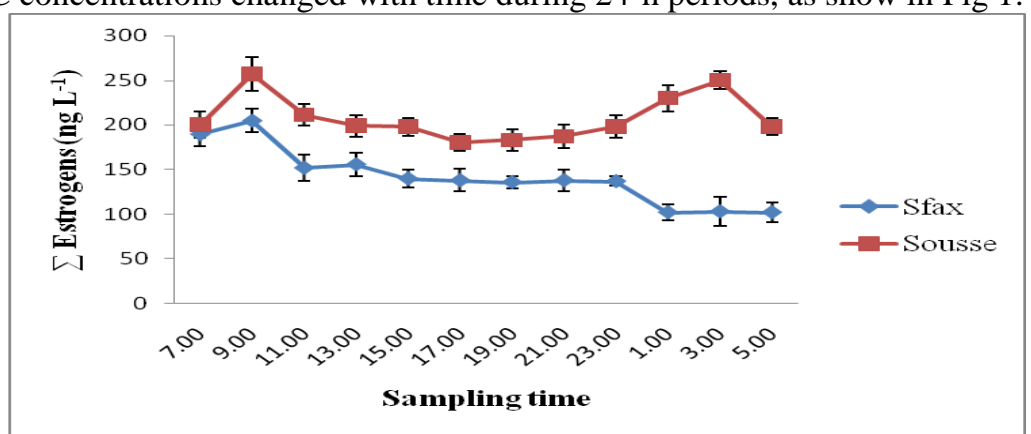

Figure 1.Comparaison of Sfax and Sousse plants influents for temporal variability of measured total steroïdal estrogens

Sfax and Sousse plants showed a total EDC concentrations (E1, E2, E3 and EE2) ranging from $190 \mathrm{ng} \mathrm{L}^{-1}$ to $205 \mathrm{ng} \mathrm{L}^{-1}$ and from $200 \mathrm{ng} \mathrm{L}^{-1}$ to $257 \mathrm{ng} \mathrm{L}^{-1}$, respectively, between 7.00 and $11.00 \mathrm{am}$, suggesting increased discharge of estrogenic compounds in the morning and the early afternoon hours. Between 11.00 am and 23.00 pm, diurnal total EDC concentrations show a progressive decrease both in Sfax and Sousse plant ranged from $152 \mathrm{ng} \mathrm{L}^{-1}$ to $137 \mathrm{ng} \mathrm{L}^{-1}$ and from $211 \mathrm{ng} \mathrm{L}^{-1}$ to $198 \mathrm{ng} \mathrm{L}^{-1}$, respectively.

In the midnight (23.00 pm to $5.00 \mathrm{am}$ ), Sfax STP shows a significant decrease of total EDC concentrations, while Sousse STP shows increment estrogens content. The reason for the significantly increase of total estrogens might be attributed to the fact that Sousse is a touristic city and very dynamic in this period. However, discharge EDCs wastewater was higher in the midnight.

The comparison between influents and effluents indicates that estrogens were not totally eliminated after the wastewater passed through the aeration tank and, as a result, were detected in most effluent samples (Table 2). In treated wastewater, E1 was detected both in Sfax and Sousse STP with a concentration of $10 \mathrm{ng} \mathrm{L}^{-1}$ and $12 \mathrm{ng}$ $\mathrm{L}^{-1}$, respectively. These values are similar to those reported in previous surveys in Japan with a median value of $12 \mathrm{ng} \mathrm{L}^{-1}$ (Komori et al., 2004) and in Italy with a median value of $9.2 \mathrm{ng} / \mathrm{L}$ (Baronti et al., 2000). The relatively high concentration of E1 in treated effluents can be caused by the transformation of E2 into E1 before being further transformed (Shi et al., 2004; Czajka and Londry, 2006). 
E2 and EE2 were detected in effluent samples of Sousse STP with concentrations of $4 \mathrm{ng} \mathrm{L} \mathrm{L}^{-1}$ and $10 \mathrm{ng} \mathrm{L}^{-1}$, respectively, probably due to the incomplete deconjugation of those compounds present in influent of this plant (Kirk et al., 2002). In treated wastewater of Sfax STP, Concentrations of those compounds were below the LOQ.

Regarding E3, it was detected only in the effluent from Sousse STP with a concentration of $15 \mathrm{ng} \mathrm{L}^{-1}$, probably due to the higher concentration of E2 in the influents of this plant and the incomplete degradation in the aeration tank. This value was higher than that previously reported by Komori et al. (2004) with a median value of $1.5 \mathrm{ng} \mathrm{L}^{-1}$ and Baronti et al. (2000) with a median value of $1.4 \mathrm{ng} \mathrm{L}^{-1}$.

\subsection{Distribution of estrogens in Tunisian STPs}

Fig. 2 shows the characteristic distributions of estrogens in the Tunisian STPs. In the Sousse plant, E3 had the largest portion in influents $(91.25 \%)$ as well as in effluents (36.55\%). As E3 is the final estrogen metabolite in human body, the Sousse-STP influent might be affected by the estrogen metabolism (Khanal et al., 2006).

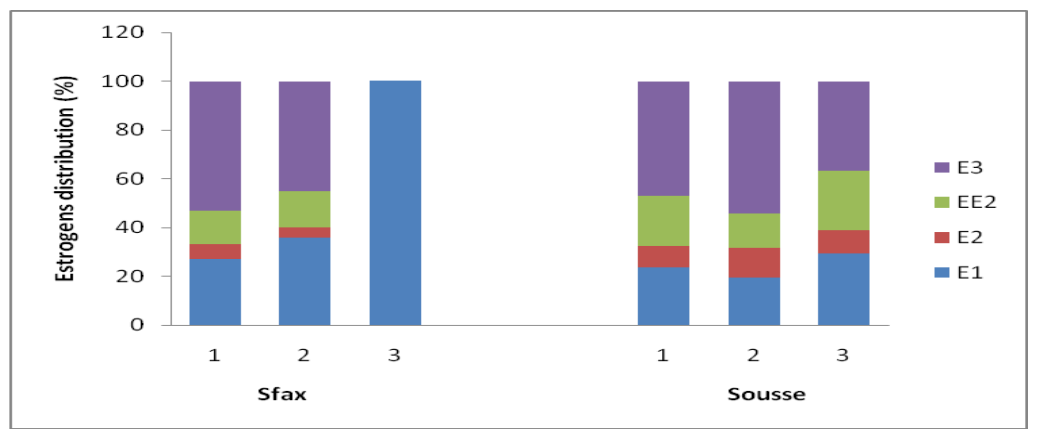

Figure 2. Distribution characterization of estrogens in wastewater from Tunisian STPs

(1: Influent; 2: Aeration tank; 3: Effluent)

The distribution tendencies of the other compounds were similar between the influents and effluents in Sousse plant. In the Sousse plant influents, the proportion of E1 $(3.87 \%)$ was the second highest, followed by EE2 $(3.43 \%)$ and E2 (1.45\%). Like the Sousse influents, in the Sousse effluents, E1 (29.42\%) was the second highest, followed by EE2 (24.36\%)) and E2 (9.66\%).

The proportion of E3 (54.50\%) in the aeration tank was dominantly found, which seems to be related to the highest concentration in the influents. The same distribution tendencies of influents and effluents were showed. E1 $(19.66 \%)$ was the second highest, followed by EE2 (14.05\%) and E2 (11.79\%).

In the Sfax plant, E3 had the largest proportion in influents $(62.12 \%)$ as well as in effluents (100\%). However, except for E3, the distribution tendencies of other compounds were different between the influents and effluents in Sfax plant. In the Sfax plant influents, the proportion of E1 (35.5\%) was the second highest, followed by EE2 $(1.68 \%)$ and E2 $(0.70 \%)$. The distribution of estrogens in the Sfax plant influents was different from the result in the Sousse plant influents, which might be attributed to the fact that STP of Sousse processed wastewater from various sources, including domestic, touristic and hospital waste effluents, and our findings may be reflective of the local environment.

Unlike the Sousse plant influents, only E1 was detected in the effluents of Sfax plant. Both STPs have biological treatment processes as the main treatment process, but the concentration transition of estrogens in each STP was different. In Sfax plant's aeration tank, the proportion of E3 (0.15\%) was low compared with the influent wastewater which seems to be related to the biodegradation of these pollutants through the biological treatment processes (Li et al., 2005). Beside this compound, E1 (65.02\%), EE2 (27.64\%) and E2 (7.3\%) were also found.

\subsection{Daily loads of estrogens from Tunisian STPs}

Fig. 3 shows the daily loads of estrogens in the STPs. Because the two plants had different number inhabitants, daily load was calculated by multiplying the total concentration of estrogens by the flow rate influents per 1000 inhabitants (Sim et al., 2011). Despite the greatest operation capacities of Sfax plant (50000 $\left.\mathrm{m}^{3} \mathrm{~d}^{-1}\right)$, Sfax and Sousse plants had approximately similar daily load of influent, $\left(112.7 \mu \mathrm{g} \mathrm{d}^{-1}\right)$ and $(109.58 \mu \mathrm{g}$ $\left.\mathrm{d}^{-1}\right)$, respectively. In the Sousse plant effluents, the load of estrogens $(2.38 \mu \mathrm{g} / \mathrm{d})$ was low compared to that in the influent, but this level was higher than the Sfax plant $\left(0.75 \mu \mathrm{g} \mathrm{d}^{-1}\right)$. This might be attributed to the poor performance of the treatment plant at Sousse.

In Sfax plant aeration tank, the daily load of estrogens $\left(6.15 \mu \mathrm{g} \mathrm{d}^{-1}\right)$ was higher than that in Sousse plant $\left(1.78 \mu \mathrm{g} \mathrm{d}^{-1}\right)$, which seems to be related to the flow rate of the aeration tank. However, only the $1 / 3$ of the average flow of Sousse plant $\left(17000 \mathrm{~m}^{3} \mathrm{~d}^{-1}\right)$ passed into the aeration tank because the plant was overloaded throughout the year. 


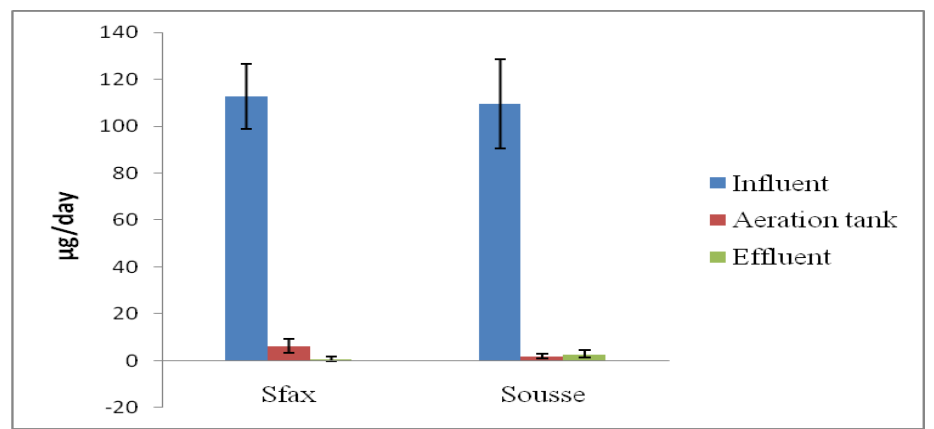

Figure 3 Daily emission amounts of estrogens in wastewater

\subsection{Removal efficiencies of estrogens from the dissolved phase}

Removal of dissolved estrogens may be highly dependent on the configurations and operation conditions of individual STP as well as wastewater characteristics. The wastewater characteristics in effluent of Sfax plant show a higher removal of COD, BOD, TSS, TN and TP than the Sousse plant (Table 3), indicating a higher performance of the anoxic/aerobic process than the simple activated sludge process. As a result, an effective removal of estrogens from the Sfax wastewater was observed (Table 2).

Table 3. Wastewater characteristics $\left(\mathrm{mg} \mathrm{L}^{-1}\right)$ of Tunisia STPs $(\mathrm{n}=2)$

\begin{tabular}{|c|c|c|c|c|c|c|c|c|c|c|}
\hline \multirow{2}{*}{ Sampling site } & \multicolumn{5}{|c|}{ Sfax } & \multicolumn{5}{|c|}{ Sousse } \\
\hline & COD & BOD & TSS & TN & TP & COD & BOD & TSS & TN & TP \\
\hline Influent & 1102 & $\begin{array}{l}499 \\
18)\end{array}$ & 380 & 70 & 20 & 775 & 298 & 260 & 75.9 & 16 \\
\hline Effluent & $\begin{array}{l}100 \\
(0.9)\end{array}$ & $\begin{array}{c}41 \\
(0.7)\end{array}$ & $\begin{array}{c}30 \\
(1.1)\end{array}$ & $\begin{array}{c}6 \\
(0.8)\end{array}$ & $\begin{array}{c}1.2 \\
(0.2)\end{array}$ & $\begin{array}{l}114 \\
(1.3)\end{array}$ & $\begin{array}{c}52 \\
(0.8)\end{array}$ & $\begin{array}{l}45 \\
(1)\end{array}$ & $\begin{array}{c}44 \\
(0.8)\end{array}$ & $\begin{array}{c}6 \\
(0.5)\end{array}$ \\
\hline Removal (\%) & 90.9 & 91.5 & 92 & 90 & 94 & 85 & 82.5 & 82.5 & 42 & 62 \\
\hline
\end{tabular}

Results indicated that among the steroid estrogens, E1 showed the lowest removal in Sfax and Sousse plants, (80\% and $76.5 \%$, respectively). The removal of E1 was somewhat lower than that of the other estrogens. This could be caused by conversion of E2 to E1 in the treatment process, as other researchers have suggested (Ternes et al., 1999), or by cleavage of estrogen conjugates (Carbella et al., 2004). These results are in agreement with those reviewed by Nie et al. (2011) with a mean removal rate from the dissolved phase of around $75 \%$ and by Baronti et al. (2000) with a mean removal rate of around $61 \%$. E3 showed the highest removal in both Sfax and Sousse plants, $(97.5 \%$ and $85.5 \%$, respectively).

E2, E3 and EE2 can be considered as completely removed since they were not detected in the effluents. It has been reported that high HRT may contribute to an increased removal rate of estrogens (Clara et al., 2005). Sfax plant with a higher HRT (40 h), was shown to have a relatively high and stable removal of both natural and synthetic estrogens, due to increased contact time of the target compounds with microorganisms in the treatment reactors. This tendency is consistent with previous studies (Clara et al., 2005, Johnson et al., 2005, Servos et al., 2005)

Several studies mentioned that STPs with nitrification showed a better removal of natural estrogens than STPs without nitrification (Anderson et al., 2003, Servos et al., 2005, Hashimoto et al., 2007). Sfax plant has treatment stages for the removal of nitrogen, and which makes the plant more effective for removing estrogenicity due either to the anoxic step, or more probably to prolonged duration of the biological steps.

In the Sousse plant, all estrogens were detected in the final effluents. E1 levels were apprximately $12 \mathrm{ng} \mathrm{L}^{-1}$, $\mathrm{E} 2$ was about $4 \mathrm{ng} \mathrm{L}^{-1}, \mathrm{E} 3$ was $15 \mathrm{ng} \mathrm{L}^{-1}$ and EE2 was $10 \mathrm{ng} \mathrm{L}^{-1}$. Despite the low concentrations measured in the plant effluents, it is important to remember that sex hormones (E1 and E2) are capable of exerting estrogenic effects at even lower concentrations than those detected in the effluents. Removal achieved for the natural estrogens was $76.5 \%$ for E1, 79\% for E2 and $85.5 \%$ for E3. Short wastewaters hydraulic retention times $(4 \mathrm{~h})$ were considered responsible for the poor performance of the Sousse plant.

A poor removal of synthetic estrogen was also detected in Sousse plant (77.5\%). EE2 is metabolized in human body before its excretion and found then in conjugated forms (Jürgens., 2002). This conjugation increases its water solubility, and thus this compound becomes more mobile in the environment than its free form (Kozak., 2001). In addition, the presence of an ethinyl group at one hydroxyl group containing C-atom is vulnerable to microbial attack. A cleavage of this ring therefore difficult what makes EE2 much more recalcitrant in the environment. Indeed, Turan (1995) reported no change in EE2 concentration over $120 \mathrm{~h}$ of treatment. Moreover, Vader et al. (2000), and Yi and Harper (2007) found that under non-nitrifying conditions, there was no degradation of EE2, while nitrifying sludge oxidizing EE2 to more hydrophobic compounds. Layton et al. (2000) also observed in laboratory experiments that sludge, which failed to nitrify, also failed to 
degrade EE2. The lower removal efficiencies of EE2 in Sousse-STP can be partly ascribed to their more hydrophobic nature, their highest occurrence in the influents, and their persistence under microbial attack. Also the short hydraulic retention time (4h) and the overloading of the plant could be responsible.

On the other hand, since EE2 is the more hydrophobic compound than the other estrogens, sorption to floc biomass is likely to play a significant role in removal (Johnson and Sumpter., 2001). Moreover, the floc disruption may impact the bioavailability of EE2 by making parent compound available to bacterial cells located throughout the aggregate (Yi et al., 2011). This tendency was consistent with the microscopic examination of the activated sludge flocs.

\subsection{Microscopic examination of the activated sludge flocs}

Microscopic examination of the activated sludge flocs taken from the aeration tanks of the STPs, as show in Fig. 4, illustrated that the flocs of Sfax STP are more compact and agglomerate than those of the Sousse STP; Sfax-STP harbored more diverse protozoa communities with higher relative abundance of crawling ciliate such us Aspidisca and attached ciliate such us Vorticella, than Sousse STP.

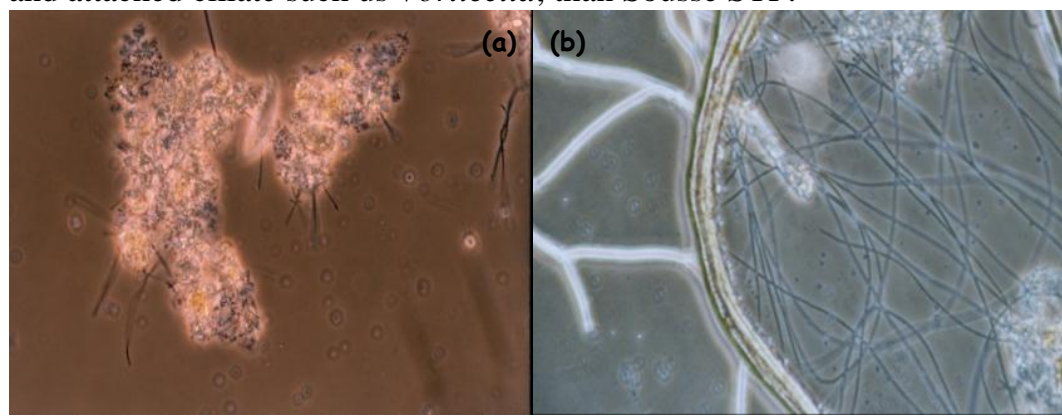

Figure 4. Microscopic examination of activated sludge flocs from Sfax-STP (a) and Sousse-STP (b) (Magnification X 1320)

An overgrowth of filamentous microorganisms (Nocardia and Thiothrix) with right-angled branching was observed in the activated sludge of Sousse-STP, mainly due to the abundant presence of fats which can be explained by the bad functioning of fats separator, and a limited transfer of oxygen into the floc and into the purifying biomass (Martins et al., 2003). Moreover, in term of nutritional balance (C/N/P), it appears that the concentration of nitrogen at the entrance of the plant was closed to $60 \mathrm{mg} \mathrm{L}^{-1}$, with an average BOD of $360 \mathrm{mg}$ $\mathrm{L}^{-1}$, there is a ratio of six times between carbon, nitrogen and phosphor. This imbalance can be regarded as among the possible causes of filamentous bacteria growth in the aeration tank of the Sousse-STP.

Nocardia had a relatively strong affinity for non-readily biodegradable fatty acids (Tsang et al., 2008). This could explain the persistence of the estrogens, especially EE2which is very hydrophobic, under the activated sludge treatment process of Sousse STP.

It is probable that removal could be affected by types of treatment process, HRT, and flocs morphology. However, nothings are known about the influence of estrogens on flocs morphology and purifying biomass in activated sludge. Further study is required to clarify this tendency.

\section{Conclusions}

The occurrence of natural and synthetic estrogens in Tunisian sewage treatment plants was investigated by sampling followed by SPE, derivatization and GC-MS analysis. The removal efficiency of estrogens in the alternating anoxic/aerobic and the simple activated sludge processes was compared. The daily loads of estrogens in the STPs using the total concentrations and flow rates of wastewater and the daily variation in influent concentrations were estimated. The microscopic examinations of the activated sludge flocs were established. The conclusions are summarized as follows:

(1) The Sousse plant, with a simple activated sludge process, showed higher concentrations of natural and synthetic estrogens in influents as well as in effluents. Removal of estrogens depend on the configurations and operation conditions of individual STP as well as wastewater characteristics. The Sfax plant with higher HRT and treatment stages for the removal of nitrogen showed a higher removal of both natural and synthetic estrogens, whereas the Sousse plant with lower HRT had a lower removal.

(2) Estrogen discharge in Sfax STP increased in the morning while Sousse STP showed increasing estrogens content in the morning and the midnight.

(3) E1 showed the lowest removal of all estrogens both in the Sfax and Sousse plants $(80 \%$ and $76.5 \%$, respectively). This was interpreted as being caused by the conversion of E2 to E1 in the treatment process, and/or by the cleavage of estrogen conjugates. The results are similar to those previously reported.

(4) E3 showed the highest removal of all estrogens both in the Sfax and Sousse plants (97.5\% and 85.5\%, respectively). 
(5) A relatively poor EE2 removal (77.5\%) was detected in the Sousse plant due to the overload of this plant, the highest concentrations of this compound in the influents, the short hydraulic retention time, and the absence of nitrifying conditions.

(6) Activated sludge microfauna was strongly affected by the operation conditions of certain system and by the presence of toxic substances in the influents such us fats which may have a stressful influence on the balance of various microorganism population, and impose growth inhibiting conditions. Filamentous bacteria were less effective in removing estrogens compared to protozoa.

\section{Acknowledgments}

The authors would like to thank the local authorities in Tunisia for kindly allowing us to take wastewater samples.

\section{References}

[1]. Andersen H, Siegrist H, Halling-Sørensen B, Ternes TA. Fate of estrogens in a municipal sewage treatment plant. Environ. Sci. Technol. (2003); 37: 4021- 4026.

[2]. Baronti C, Curini R, D’Ascenzo G, Di Corcia A, Gentili A, Samperi R. Monitoring natural and synthetic estrogens at activated sludge sewage treatment plants and its receiving river water. Environ. Sci. Technol. (2000); (24): 5059-5066.

[3]. Belhaj D, Jaabiri I, Ayadi H, Kallel M, Zhou JL. Occurrence and removal of steroidal estrogens in Centre Eastern Tunisia municipal sewage treatment plant. Dessalination and Water Treatment. (2013): 1-10.

[4]. Benotti MJ, Trenholm RA, Vanderford BJ, Standford BD, Snyder SA. Pharmaceuticals and endocrine disrupting compounds in U.S. drinking water. Environ Sci Technol. (2009); 43: 597-603.

[5]. Boyd RG, Palmeri JM, Zhang S, Grim DA. Pharmaceuticals and personal care products (PPCPs) in stormwater canals and Bayou St. John in New Orleans, Louisiana. Sci Total Environ. (2004); 333: 137-148.

[6]. Carballa M, Omil F, Lema J M, Llompart M, Garcia-Jares C, Rodriguez I, Gomez M. Ternes T. Behavior of pharmaceuticals, cosmetics and hormones in a sewage treatment plant,Water Res. (2004); 38: 2918-2926.

[7]. Cargouet M, Perdiz D, Mouatassim-Souali A, Tamisier-Karolak S, Levi Y. Assessment of river contamination by estrogenic compounds in Paris area (France). Sci Total Environ (2004); 324: 55-66.

[8]. Czajka CP, Londry KL. Anaerobic biotransformation of estrogens. Sci Total Environ. (2006);367:932-41.

[9]. Clara M, Kreuzinger N, Strenn B, Gans O, Kroiss H. The solids retention time - a suitable design parameter to evaluate the capacity of wastewater treatment plants to remove micropollutants. Water Res. (2005); 39; 97-106.

[10]. Eikelboom DH. Process control of activated sludge plants by microscope investigation. IWA Publishing, London. 2000.

[11]. Fawell JK, Sheahan D, James HA, Hurst M, Scott S. Oestrogens and oestrogenic activity in raw and treated water in severn trent water.Water Res. (2001); 35: 1240-4.

[12]. Fort DJ, Guiney PD, Weeks JA, Thomas JH, Rogers RL, Noll AM, Spaulding CD. Effect of methoxychlor on various life stages of Xenopus laevis. Toxicol. Sci. (2004); 81: 454-466.

[13]. Grover D, Zhou JL, Frickers PE, Readman JW. Improved removal of estrogenic and pharmaceutical compounds in sewage effluent by full scale granular activated carbon: Impact on receiving river water. J. Hazardous Materials. (2011); 185: 1005-1011.

[14]. Gulkowska A, Leung HW, So MK, Taniyasu S, Yamashita N, Yeung LWY, Richardson BJ, Lei AP, Giesy JP, Lam PKS. Removal of antibiotics from wastewater by sewage treatment facilities in Hong Kong and Shenzhen, China. Water Res. (2008); 42: 395-403.

[15]. Hachicha S, Sellami F, Cegarra J, Hachicha R, Drira N, Methioub KH, Ammar E. Biological activity during co-composting of sludge issued from the OMW evaporation ponds with poultry manure-Physico-chemical characterization of the processed organic matter. Journal of Hazardous Materials. (2009); 162: 402-409.

[16]. Hashimoto T, Onda K, Nakamura Y, Tada K, Miya A, Murakami T. Comparison of natural estrogen removal efficiency in the conventional activated sludge process and the oxidation ditch process. Water. Res. (2007); 41: 2117-2126.

[17]. Hayes T, Haston K, Tsui M, Hoang A, Haeffele C, Vonk A. Atrazine-induced hermaphroditism at 0.1 ppb in American leopard frogs (Rana pipiens): laboratory and field evidence. Environ. Health Perspect.( 2003); 111: 568-575.

[18]. Heidler J, Halden RU. Mass balance of triclosan removal during conventional sewage treatment. Chemosphere. (2007); 66: 362369.

[19]. Jeannot R, Sabik H, Sauvard E, Dagnac T, Dohrendorf K. Determination of endocrine-disrupting compounds in environmental samples using gas and liquid chromatography with mass spectrometry. J. Chromatogr. (2002); 974: 143-159.

[20]. Jobling S, Casey D, Rodgers-Gray T, Oehlmann J, Schulte- Oehlmann U, Pawlowski S, Baunbeck T, Turner AP, Tyler CR Comparative responses of molluscs and fish to environmental estrogens and an estrogenic effluent. Aquat. Toxico. (2003); 65: 205220.

[21]. Johnson AC, Sumpter JP. Removal of endocrine-disrupting chemicals in activated sludge treatment works. Environ Sci Technolo (2001); 35: 4697-703.

[22]. Johnson AC, Aerni H R, Gerritsen A, Gibert M, Giger W, Hylland K, Jurgens M, Nakari T, Pickering A, Suter MJ, Svenson A, Wettstein FE. Comparing steroid estrogen and nonylphenol content across a range of European sewage plants with different treatment and management practices. Water Res. (2005); 39: 47-58.

[23]. Joss A, Zabizynski S, Göbel A, Hoffmann B, Löffler D, McArdell CS, Termes TA, Thomsen A, Siegrist H. Removal of pharmaceuticals and fragrances biological wastewater treatment. Water Res. (2005); 40: 1686-1696.

[24]. Jürgens MD, Nolthans KIE, Johnson AC, Smith JJL. The potential for estradiol and ethynilestradiol degradation in English rivers. Environ Toxicolol Chem. (2002); 21: 480-8.

[25]. Khanal SK, Xie B, Thompson ML, Sung S, Ong SK, van Leeuwen J. Fate, transport, and biodegradation of natural estrogens in the environment and engineered systems. Environ. Sci. Technol. (2006); 40: 6537-6546.

[26]. Kim SD, Cho J, Kim IS, Vanderford BJ, Snyder SA. Occurrence and removal of pharmaceuticals and endocrine disruptors in South Korean surface, drinking, and waste waters, Water Res. (2007); 41: 1013-1021.

[27]. Kirk LA, Tyler CR, Lye CM, Sumpter JP. Changes in estrogenic and androgenic activities at different stages of treatment in wastewater treatment works. Environ Toxicol Chem (2002);21:972-9.

[28]. Knechtel RJ. A more economical method for the determination of chemical oxygen demand. Water Pollut. (1978); 25-29.

[29]. Kozak RG, D'Haese I, Vestraete W. Pharmaceuticals in the environment: focus on 17 $\alpha$-ethinylestradiol. In: kümmerer K, editor. Pharmaceuticals in the environment. Sources, fate, effects and risk. Heidelberg, Germany: Springer Verlag. (2001); 49-65. 
[30]. Kloas W, Lutz I. Amphibians as model to study endocrine disrupters. J. Chromatogr.A, (2006); 1130: 16-27.

[31]. Kwak HI, Bae MO, Lee MH, Lee YS, Lee BJ, Kang KS, Chae CH, Sung HJ, Shin JS, Kim JH, Mar WC, Sheen YY, Cho MH. Effects of nonylphenol, bisphenol A, and their mixture on the viviparous swordtail fish (Xiphophotus helleri). Environmental Toxicology and Chemistry. (2001); 20: 787-795.

[32]. Layton AC, Gregory BW, Seward JR, Schultz TW, Sayler GS. Mineralization of steroidal hormones by biosolids in wastewater treatment systems in Tennessee, USA. Environ Sci Technol (2000); 34: 3925-3931.

[33]. Lee HB, Peart TE, Gris G, Chan J. Endocrine-disrupting chemicals in industrial wastewater samples in Toronto, Ontario. Water Qual. Res. J. Can. (2002); 37: 459-472.

[34]. Lee SK, Veeramachaneni DNR.. Subchronic exposure to low concentrations of di-n-Butyl Phthalate disrupts spermatogenesis in Xenopus laevis frogs. Toxicol. Sci. (2005); 84: 394-407.

[35]. Levy G, Lutz I, Kruger A, Kloas W. Bisphenol A induces feminization in Xenopus laevis tadpoles. Environ. Res. (2004); 94 : 102111

[36]. Li F, Yuasa A, Obara A, Mathews AP. Aerobic batch degradation of 17-b estradiol (E2) by activated sludge: effects of spiking E2 concentrations, MLVSS and temperatures. Water Res. (2005); 39: 2065-2075.

[37]. Liu R, Wilding A, Hibberd A, Zhou JL. Partition of endocrine- disrupting chemicals between colloids and dissolved phase as determined by cross flow ultrafiltration. Environ. Sci. Technol. (2005); 39: 2753-2761.

[38]. MacKenzie CA, Berrill M, Metcalfe C, Pauli BD. Gonadal differentiation in frogs exposed to estrogenic and antiestrogenic compounds. Environ. Toxicol. Chem. (2003); 22: 2466-2475.

[39]. Martins AMP, Van Loosdrecht MCM, Heijnen JJ. Effect of dissolved oxygen concentration on the sludge settleability. Applied Microbio Biotech. (2003); 62: 586-593.

[40]. Miege C, Choubert JM, Ribeiro L, Eusebe M, Coquery M. Fate of pharmaceuticals and personal care products in wastewater treatment plants — conception of a database and first results. Environ Pollut.(2009); 157: 1721-6.

[41]. Mills LJ, Chichester C. Review of evidence: are endocrine-disrupting chemicals in the aquatic environment impacting fish populations? Sci Total Environ. (2005); 343: 1-34.

[42]. Nakada N, Tanishima T, Shinohara H, Kiri K, Takada H. Pharmaceutical chemicals and endocrine disrupters in municipal wastewater in Tokyo and their removal during activated sludge treatment. Water Research. (2006); 40: 3297- 3303.

[43]. Nie Y, Qiang Z, Zhang H, Adams C. Determination of endocrine-disrupting chemicals in the liquid and solid phases of activated sludge by solid phase extraction and gas chromatography-mass spectrometry, J. Chromatogr. A. (2009); 1216: 7071-7080.

[44]. Nie Y, Qiang Z, Zhang H, Ben W. Fate and seasonal variation of endocrine-disrupting chemicals in sewage treatment plant with A/A/O process. Separation and Purification Tech. (2011).

[45]. Petrovic M Sole M, Lopez de Alda MJ, Barcelo D. Endocrine disruptors in sewage treatment plants, receiving river waters, and sediments: integration of chemical analysis and biological effects on feral carp. Environ Toxicol Chem (2002); 21: 2146-56.

[46]. Safe SH. Endocrine disruption and human health-is there a problem? An update, Environ. Health Perspect (2000); 108: 487-493

[47]. Servos MR, Bennie DT, Burnison BK, Jurkovic A, McInnis R, Neheli T, Schnell A, Seto P, Smyth SA, Ternes TA. Distribution of estrogens, 17 b-estradiol and estrone, in Canadian municipal wastewater treatment plants. Sci. Total Environ. (2005); 336: 155-160.

[48]. Shi J, Fujisawa S, Nakai S, Hosomi M. Biodegradation of natural and synthetic estrogens by nitrifying activated sludge and ammonia-oxidizing bacterium Nitrosomonas europaea. Water Research. (2004); 38: 2323-2330.

[49]. Sim JW, Lee JW, Shin SK, Song KB, Oh JE. Assessment of fates of estrogens in wastewater and sludge from various types of wastewater treatment plants. Chemeosphere. (2011); 82: 1448-1453.

[50]. Stasinakis AS, Gatidou G, Mamais D, Thomaidis NS, Lekkas TD. Occurrence and fate of endocrine disrupters in Greek sewage treatment plants. Water research. (2008); 42: 1796- 1804.

[51]. Stasinakis, AS, Constantinos I, Kordoutis A, Vasiliki C, Tsiouma A, Georgia Gatidou A, Nikolaos S, Thomaidis B. Removal of selected endocrine disrupters in activated sludge systems: Effect of sludge retention time on their sorption and biodegradation. Bioresource Technology. (2010); 101: 2090-2095

[52]. Ternes TA, Stumpf M, Mueller J, Haberer K, Wilken RD, Servos M. Behavior and occurrence of estrogens in municipal sewage treatment plants-I. Investigations in Germany, Canada and Brazil. Sci. Total Environ. (1999); 225: 81-90.

[53]. Ternes TA, Joss A. Human Pharmaceuticals, Hormones and Fragrances: the challenge of micropollutants in urban water management. IWA Publishing; 2006

[54]. Tsang YF, Sin SN, Chua M, Nocardia-foaming control in activated sludge process treating domestic wastewater. Bioress Technol. (2008); 99: 3381-3388

[55]. Vader JS, van Ginkel CG, Sperling FM , Jong J, Boer W, Graaf JS. Degradation of ethinyl estradiol by nitrifying activated sludge. Chemosphere (2000); 41: 1239-1243.

[56]. Yi T, Harper WF. The effect of biomass particle characteristics on the partitioning and sorption hysteresis of 17aethinylestradiol. Water Res. (2007); $41: 1543-1553$

[57]. Zhang Y and Zhou JL. Occurrence and removal of endocrine disrupting chemicals in wastewater. Chemosphere. (2008); 73: 848853

[58]. Zhou JL, Zhang ZL, Banks E, Grover D, Jiang JQ. Pharmaceutical residues in wastewater treatment works effluents and their impact on receiving river water. Journal of Hazardous Materials (2009); 166: 655-661.

[59]. Zhou KX, Xu MQ, Dau JY, Cao H. Microfauna communities and operational monitoring of an activated sludge plant in China. European journal of Protistology. (2006); 42: 291-295. 